\title{
Prevalence and factors associated with road traffic incident among adolescents and children in the hospitals of Amhara National Regional State, Ethiopia
}

\author{
Bewket Tadesse Tiruneh $^{1 *}$ D, Berhanu Boru Bifftu ${ }^{1}$ and Berihun Assefa Dachew ${ }^{2}$
}

\begin{abstract}
Background: Road Traffic Incident (RTI) has been commonly reported as a major public health problem around the world and the incidence is higher in low and middle income countries, such as Ethiopia than high income countries. The aim of this study was to assess the prevalence and factors associated with RTI among adolescents and children in the hospitals of Amhara Regional State, Ethiopia.

Methods: A cross-sectional study design was employed among 830 injured children visiting the Emergency Department of four randomly selected hospitals of Amhara Regional State, Ethiopia between February 1 and April 30, 2016. Data were entered into EPI info version 7 and then exported to SPSS version 20, for further analysis. Univariable and multivariable logistic regression models were fitted. Adjusted odds ratio with its $95 \%$ confidence interval was used to determine the statistical significance.

Results: The overall prevalence of RTI, from all injury cases, was 20\%. Socioeconomic status, being wealthy (AOR: 0 . $08,95 \% \mathrm{Cl}, 0.01,0.45$ ) and middle income (AOR: $0.40,95 \% \mathrm{Cl}, 0.17,0.97$ ), parental/guardian education/no education (AOR: 6.91, 95\% Cl, 2.52, 8.93), mothers marital status/divorced (AOR: $0.01,95 \% \mathrm{Cl}, 0.01,0.05$ ), and leaving a child with another child for sometime (AOR: 2.56, Cl 1.06, 6.20) and most often (AOR: 4.77, Cl, 1.15, 9.77) were factors independently associated with RTI .

Conclusion and recommendation: The prevalence of RTI was found to be high. RTI prevention needs critical consideration and the intervention strategies shall focus on those families who are practicing of leaving a child with another child.
\end{abstract}

Keywords: Adolescent, Children, Factors, Prevalence, Road Traffic Incident

\section{Background}

Nations of the world have been implementing different strategies towards Road Traffic Incident (RTI), which encompass improving the road system, limiting the speed, enforcement to use seat belts, drink-driving laws, prohibition for phoning during driving and wearing helmets [1]. However, RTI is still continuing as one of the major public health concern and estimated to be one of leading cause of death in the year 2030 [2]. Furthermore,

\footnotetext{
* Correspondence: jeryfiker21@gmail.com

${ }^{1}$ College of Medicine and Health Science, School of Nursing, University of Gondar, P.O.Box: 196, Gondar, Ethiopia

Full list of author information is available at the end of the article
}

the sequels of being injured in RTI can result in mental and psychological health problems [3].

Globally, the pediatric age population accounted for $21 \%$ of RTI related deaths. Data in Great Britain in 2011 showed that RTI was responsible for the death or injury of 2412 children under the age of 16 years. RTI is the leading cause of disability and death for children in Europe, even with a strives to prevent the problem, and create an environment where no child death due to RTI [4]. Data suggests that $93 \%$ of child road traffic incident deaths occur in low and middle-income countries [5].

Studies revealed that RTI showed a significant rise in Africa in 2014. For example, the death rate for Kenyans

(c) The Author(s). 2019 Open Access This article is distributed under the terms of the Creative Commons Attribution 4.0 International License (http://creativecommons.org/licenses/by/4.0/), which permits unrestricted use, distribution, and reproduction in any medium, provided you give appropriate credit to the original author(s) and the source, provide a link to the Creative Commons license, and indicate if changes were made. The Creative Commons Public Domain Dedication waiver (http://creativecommons.org/publicdomain/zero/1.0/) applies to the data made available in this article, unless otherwise stated. 
Table 1 Socio-demographic characteristics of study participants, Amhara National, Regional State Referral Hospitals Ethiopia, 2016 $(n=830)$

\begin{tabular}{|c|c|c|}
\hline Variables & & $\begin{array}{l}\text { Frequency } \\
(\%)\end{array}$ \\
\hline \multirow[t]{4}{*}{ Age of parents/guardians in years } & $50-64$ & $58(7.0)$ \\
\hline & $35-49$ & $168(20.2)$ \\
\hline & $<30$ & $273(32.9)$ \\
\hline & $25-34$ & $331(39.9)$ \\
\hline \multirow[t]{2}{*}{ Sex of children } & Female & $322(38.8)$ \\
\hline & Male & $508(61.2)$ \\
\hline \multirow[t]{3}{*}{ Age of children } & $<5$ & $132(15.9)$ \\
\hline & $5-10$ & $281(33.9)$ \\
\hline & $11-17$ & $417(50.2)$ \\
\hline \multirow[t]{3}{*}{ Children live with } & Guardian & $149(18)$ \\
\hline & $\begin{array}{l}\text { Father or } \\
\text { mother }\end{array}$ & $318(38.3)$ \\
\hline & Both parents & $363(43.7)$ \\
\hline \multirow[t]{4}{*}{ Occupation of the mother } & Day laborer & $30(3.6)$ \\
\hline & Employee & $126(15.2)$ \\
\hline & Petty trader & $163(19.6)$ \\
\hline & Housewife & $511(61.6)$ \\
\hline \multirow[t]{4}{*}{ Occupation of the father } & Farmer & $385(46.4)$ \\
\hline & Employ & $235(28.3)$ \\
\hline & Petty trader & $88(10.6)$ \\
\hline & Day laborer & $122(14.7)$ \\
\hline \multirow[t]{5}{*}{ Marital status of the mother } & Divorced & $23(2.8)$ \\
\hline & Separated & $26(3.1)$ \\
\hline & Single & $56(6.7)$ \\
\hline & Widow & $71(8.6)$ \\
\hline & Married & $654(78.8)$ \\
\hline \multirow[t]{5}{*}{ Marital status of the father } & Divorced & $25(3.0)$ \\
\hline & Separated & $39(4.7)$ \\
\hline & Widow & $47(5.7)$ \\
\hline & Single & $58(7.0)$ \\
\hline & Married & $661(79.6)$ \\
\hline \multirow[t]{4}{*}{$\begin{array}{l}\text { Educational status of the parents or } \\
\text { guardians }\end{array}$} & $\begin{array}{l}\text { College } \\
\text { education }\end{array}$ & $95(11.4)$ \\
\hline & $\begin{array}{l}\text { Second } \\
\text { education }\end{array}$ & $153(18.4)$ \\
\hline & $\begin{array}{l}\text { Primary } \\
\text { education }\end{array}$ & $179(21.6)$ \\
\hline & No education & $403(48.6)$ \\
\hline \multirow[t]{5}{*}{ Child educational statues } & College & $6(0.7)$ \\
\hline & Nursery & $51(6.1)$ \\
\hline & Secondary & $125(15.1)$ \\
\hline & No education & $216(26.0)$ \\
\hline & Primary & $432(52.0)$ \\
\hline
\end{tabular}

Table 1 Socio-demographic characteristics of study participants, Amhara National, Regional State Referral Hospitals Ethiopia, 2016 $(n=830)$ (Continued)

\begin{tabular}{lll}
\hline Variables & & $\begin{array}{l}\text { Frequency } \\
(\%)\end{array}$ \\
\hline $\begin{array}{l}\text { Income description of the parents/ } \\
\text { guardians }\end{array}$ & Wealthy & $53(6.4)$ \\
& Low & $271(32.7)$ \\
& Middle & $506(61.0)$ \\
\hline
\end{tabular}

was 19.0 persons per 100,000, while the Ethiopians was 37.3persons per 100,000 in 2014 [6].The road users, the environment, and the condition of the vehicles were factors associated with RTI in Ethiopia. In the year 2005, $93 \%$ of the accidents were accounted for road users, and the rest 5 and $2 \%$ were accounted for road environment and vehicle related factors respectively. The capital city of Ethiopia, Addis Ababa, and the Oromia National Regional State accounted for nearly $60 \%$ of RTI in Ethiopia [3].The government of Ethiopia introduced a number of strategies towards reduction of RTI, which includes safety awareness program, with further scale up of a campaign, improving visibility of road users, following the compliance of drivers with road safety rules [7]. However, RTI is still a common cause of morbidity and mortality in Ethiopia. There is paucity of data on RTI in Ethiopia and to the best of the authors' knowledge no study among children [8]. Having data on the burden of RTI and identifying the associated factors would help policy-makers and program managers in developing responses for the prevention of RTI. Therefore, this study was designed to determine the prevalence of RTI and to identify factors associated with among children in Amhara National Regional State, Ethiopia.

\section{Methods}

This study was a cross-sectional study design, conducted in four selected hospitals of Amhara National Regional State, Ethiopia (University of Gondar Hospital, Felegehiwot Hospital, Debark Hospital, and Debertabour Hospital), from February 1 to April 30, 2016.These hospitals were randomly selected and included in the study. In this study, all children under the age of 18 visiting the Emergency Department(ED) of these hospitals, due to any forms of injury, was included. Systematic random sampling techniques were used to select study participants in the ED of each hospital. A single population proportion formula was used to determine the sample size and the following assumptions made: $95 \%$ confidence level, $5 \%$ margin of error and taking prevalence of $50 \%$. Considering a $10 \%$ non-response rate, the sample size becomes 423. Taking in to account design effect of two, the final sample size was 846 . 
Data were collected using an interviewer-administered questionnaire which was prepared by reviewing different studies conducted on injury, including RTI [9-11]. To maintain data quality, training was given to data collectors and supervisors. In addition, supervision was carried out on daily basis during the data collection to check completeness and consistency of the data, both by the supervisors and investigators. The collected data was entered and cleaned using EPI-INFO and analyzed using SPSS version 20. Frequency distributions and percentages were calculated to describe socio-demographic characteristics. Simple and multivariable logistic regression analyses were used to explore associations between RTI and dependent variables. Odds ratios and 95\% confidence intervals were used as measures of association. A $p$-value less than $<0.05$ in the multivariable model were accepted as statistically significant.

\section{Results}

\section{Socio-demographic characteristics of respondents}

Out of 846 study participants, 830 were participated in the study, making the response rate $98 \%$. Over $60 \%$ of them were male, more than a quarter of them were not in school and nearly $16 \%$ of the participants were under the age of 5 , and nearly $49 \%$ of the families were not educated. More than $46 \%$ of children's fathers were farmers by occupation, while majorities (61.2\%) of children's mothers were housewife. Nearly $44 \%$ of the children lived with both parents (Table 1).

\section{Prevalence and factors associated with RTI among adolescents and children}

In this study, the prevalence of RTI was found to be $20 \%$ (95\% CI: 17.2, 22.9). From this, 113(68.1\%) of the victims were male, $86(51.8 \%)$ of them were found in the age group of 11-17. For $121(27.1 \%)$ of the cases, cars were involved, and for $92(55.4 \%)$ of the victims RTI were experienced while crossing the road. Nearly $70 \%$ of the cases arrived in the emergency department immediately (Table 2).

\section{Factors associated with RTI among children}

In the multivariable analysis; on socioeconomic status, being wealthy (Adjusted Odd Ratios (AOR):0.08, 95\% Confidence Interval $(\mathrm{CI}), 0.01,0.45)$ and middle income (AOR:0.40,95\% CI, 0.17, 0.97), parental/guardian education/ no education (AOR:6.91, 95\% CI, 2.52 8.93), marital status of the mother, being divorced(AOR:0.01 CI, 0.01, 0.05), leaving a child with another child for supervision [sometime (AOR:2.56,95\% CI, 1.06, 6.20), and most often (AOR: 4.77, CI 1.15,9.77)] were factors statistically associated with RTI (Table 3).
Table 2 Prevalence of RTI among Adolescents and Children in the Referral Hospitals of Amhara Regional State, Ethiopia. 2016 $(n=166)$

\begin{tabular}{|c|c|c|}
\hline Characteristics & & $\begin{array}{l}\text { Frequency } \\
(\%)\end{array}$ \\
\hline \multirow[t]{2}{*}{ Sex } & Male & $113(68.1)$ \\
\hline & Female & $53(31.9)$ \\
\hline \multirow[t]{3}{*}{ Age of children in years } & Less than 5 & $22(13.3)$ \\
\hline & $6-10$ & $58(34.9)$ \\
\hline & $11-17$ & $86(51.8)$ \\
\hline \multirow[t]{4}{*}{ Age of guardian or parents } & $<30$ & $50(30.1)$ \\
\hline & $31-40$ & $68(41.0)$ \\
\hline & $41-50$ & $39(23.5)$ \\
\hline & $51-60$ & $9(5.4)$ \\
\hline \multirow[t]{2}{*}{ Type of vehicle involved } & Car & $121(27.1)$ \\
\hline & Tri -motorcycle & $45(27.1)$ \\
\hline \multirow[t]{3}{*}{ Activity at the time of injury } & Passenger & $38(22.9)$ \\
\hline & $\begin{array}{l}\text { While walking along } \\
\text { the road }\end{array}$ & $36(21.7)$ \\
\hline & $\begin{array}{l}\text { While crossing the } \\
\text { road }\end{array}$ & $92(55.4)$ \\
\hline \multirow{4}{*}{$\begin{array}{l}\text { Time of arrival at the Emergency } \\
\text { Department }\end{array}$} & Immediately & $115(69.3)$ \\
\hline & Within hours & $17(10.2)$ \\
\hline & Within a day & $31(18.7)$ \\
\hline & Within days & $3(1.8)$ \\
\hline \multirow[t]{4}{*}{ Educational level of the child } & No education & $40(24)$ \\
\hline & Nursery & $5(3.0)$ \\
\hline & Primary & $97(58.4)$ \\
\hline & Secondary & $24(14.5)$ \\
\hline \multirow[t]{5}{*}{ Mother's marital status } & Single & $13(7.8)$ \\
\hline & Married & $130(78.3)$ \\
\hline & Separated & $3(1.8 \%$ \\
\hline & Divorced & $11(6.6)$ \\
\hline & Widowed & $9(5.4)$ \\
\hline \multirow[t]{5}{*}{ Father's marital status } & Single & $16(9.6)$ \\
\hline & Married & $129(77.7)$ \\
\hline & Separated & $2(1.2)$ \\
\hline & Divorced & $11(6.6)$ \\
\hline & Widowed & $8(4.8)$ \\
\hline
\end{tabular}

\section{Discussion}

This is the first study that has assessed the prevalence and factors associated with RTI among adolescents and children in the referral hospitals of Amhara National Regional State, Ethiopia. The overall prevalence of RTI was found to be $20 \%$. This finding is higher than a study conducted in Iran, which documented a prevalence of $16.4 \%$ [12].The possible explanation of the differences between the two studies may be due to the variation of 
Table 3 Simple and Multiple Logistic Regression Analysis of Factors Associated with RTI among Adolescents and Children in the Referral Hospitals of Amhara Regional State, Ethiopia. 2016 ( $N=830)$

\begin{tabular}{|c|c|c|c|c|c|c|}
\hline \multirow[t]{2}{*}{ Variables } & & \multicolumn{2}{|l|}{ RTI } & \multicolumn{2}{|c|}{ Odds Ratio with 95\% Cl } & \multirow{2}{*}{$\begin{array}{l}P_{-} \\
\text {Value }\end{array}$} \\
\hline & & Yes & $\overline{\mathrm{No}}$ & $\overline{C O R}$ & $\mathrm{AOR}$ & \\
\hline \multirow[t]{2}{*}{ Sex of the child } & Male & 113 & 395 & $1.45(1.012 .08)$ & $1.76(0.793 .93$ & 0.16 \\
\hline & Female & 53 & 269 & 1 & 1 & 1 \\
\hline \multirow[t]{4}{*}{ Guardian level of education } & No & 92 & 311 & $1.66(1.042 .67)$ & $6.91(2.528 .93)$ & $0.001^{*}$ \\
\hline & Primary & 27 & 152 & $1.44(0.892 .34)$ & $2.58(0.857 .82)$ & 0.094 \\
\hline & Secondary & 26 & 127 & $1.04(0.611 .78)$ & $0.93(0.184 .65)$ & 0.928 \\
\hline & Tertiary & 21 & 74 & 1 & 1 & 1 \\
\hline \multirow[t]{5}{*}{ Marital status of the mother } & Single & 13 & 43 & 1 & 1 & 1 \\
\hline & Married & 130 & 524 & $1.22(0.642 .33)$ & $0.28(0.061 .25)$ & 0.095 \\
\hline & Separated & 3 & 23 & $2.32(0.598 .97)$ & 0.98 (0.07 12.95) & 0.985 \\
\hline & Divorced & 11 & 12 & $0.33(0.120 .92)$ & $0.008(0.010 .05)$ & $0.001^{*}$ \\
\hline & Widowed & 9 & 62 & 2.083 (0.818 5.303) & $0.51(0.0733 .483)$ & 0.489 \\
\hline \multirow[t]{4}{*}{ Father's Occupation } & Farmer & 74 & 311 & 1 & 1 & \\
\hline & Employed & 36 & 199 & $1.31(0.8502 .035)$ & $2.803(0.737$ 10.660) & 0.130 \\
\hline & Petty trader & 27 & 61 & $0.538(0.320 .90)$ & $0.98(0.214 .55)$ & 0.982 \\
\hline & Day laborer & 29 & 93 & $0.76(0.451 .24)$ & $3.12(0.674 .48)$ & 0.147 \\
\hline \multirow[t]{3}{*}{ leaving a child with a child } & No & 97 & 310 & 1 & 1 & 1 \\
\hline & sometimes & 56 & 267 & 1.49 (1.03 2.15) & $2.56(1.066 .20)$ & $0.037^{*}$ \\
\hline & most often & 13 & 87 & $2.09(1.1203 .91)$ & $4.77(1.159 .77)$ & $0.031^{*}$ \\
\hline \multirow[t]{2}{*}{ Child behavior } & Aggressive & 17 & 144 & $2.43(1.424 .14)$ & $1.04(0.33,3.26)$ & 0.944 \\
\hline & Unaggressive & 149 & 520 & 1 & & \\
\hline \multirow[t]{3}{*}{ Socioeconomic status } & Wealth & 15 & 38 & $0.63(0.321 .23)$ & $0.08(0.01,0.45)$ & $0.004^{*}$ \\
\hline & Middle & 97 & 409 & $1.05(0.721 .52)$ & $0.41(0.17,0.97)$ & $0.044^{*}$ \\
\hline & Low & 54 & 217 & 1 & 1 & 1 \\
\hline \multirow[t]{4}{*}{ Age of Guardian } & $<30$ & 50 & 223 & 1 & 1 & 1 \\
\hline & $31-40$ & 68 & 263 & $0.87(0.58$ 1.30) & $0.72(0.281 .84)$ & 0.492 \\
\hline & $41-50$ & 39 & 129 & 0.74 (0.46 1.19) & $0.33(0.121 .02)$ & 0.055 \\
\hline & $51-65$ & 9 & 49 & $1.22(0.562 .65)$ & 1.66 (3.74 5.58) & $0.001^{*}$ \\
\hline
\end{tabular}

1: ref reference category, $C O R$ crude odds ratio, $A O R$ adjusted odds ratio, ${ }^{*} p<0.05$

the countries in road development. Ethiopian is one of lest developed country, with poor road network [10], hence people can easily exposed to RTI at a higher level in Ethiopia somewhere else.

The current finding is also higher as compared to the study conducted in South Africa,13.3\% [13], and in India,52.61\% [14].The difference might be attributed to the study period, i.e. the South African and Indian studies were a three years study, while the current study is only a three months data analysis, in which case the result can be affected by seasonal variation of RTI occurrence.

Another study in India, on prevalence of RTI showed that the prevalence was $31 \%$ [15].The disparity may be due to study population differences, between these studies. For the Indian study, those children whose age was 18 were also included, while in the current study those children whose age was 18 were excluded. Therefore, the prevalence of Indian's study may be higher than the current finding.

The probability of RTI for adolescents and children whose guardian or family were not educated was nearly 7 times more likely to have RTI as compared to those children whose guardian or family were educated at tertiary level (AOR: 6.91, 95\% CI 2.52,8.93). Uneducated guardian or family may not have the required knowledge towards the prevention of such kind of injury. Thus, those children whose guardian or families were not educated can exposed to RTI more frequently.

The odds of RTI for children whose mother's was divorced were $99.9 \%$ less likely to have RTI as compared to those children whose mother's was single (AOR:0.01, CI 0.01,0.05). Although there was no study in line with 
this finding, the possible reason, might be in most of the Ethiopian community, following divorce, children of the divorced mother will joined their grand families, with the experiences of assisting children to grow in a well-protected manner. Thus, this practice can protect children from RTI.

In this study, leaving a child for supervision with another child is found to be a risk factor for the occurrence of RTI. The probability of RTI for children whose caregivers were leave a child with other child for supervision sometimes and most often were 2.5 and 4.7 times more likely to have RTI as compared to those children whose caregivers were not leave children with another child respectively. In Ethiopian there is an informal appointment of young's before the age of 18 in order to supervised adolescents and school aged children. This practice could potentially expose for inadequate supervision of the children population, which can expose them for injury, such as RTI.

Furthermore, the odds of RTI for children whose families income described as wealthy and middle were 92 and $59.2 \%$ less likely to have RTI as compared to those children whose families' income were described as low in that order,(AOR: 0.08, CI, 0.01, 0.45) and, (AOR:0.41, CI $0.17,0.97$ ). Socioeconomic status of any family will have a determinant role in the health and development of children in general. The wellbeing of those children of a better income family tends to be protected and the probability of facing RTI will be lower for children from higher income families. This is the reflection of poverty on the health status of children and this is supported by a study done in Canada [16]. On the other hand, children from the families of wealthy will have a better environment for health and wellbeing in general.

Furthermore, the odds of RTI for children whose guardian age was between 51 and 65 years were 1.6 times more likely to have RTI as compared to those children whose guardian age was less than 30 years (AOR: 1.66, CI 3.74 5.58). This may be due to the effect of aging, as it decreases the ability of the old family members to provided adequate supervision for child's well-being. Therefore, those children of the older age family may have RTI more frequently as compared to the children of the younger age families.

\section{Limitation of the study}

In this study, the duration of the data collection was short so that the result may be affected by seasonal occurrences of RTI. Furthermore, this study was a hospital based study so it may not generalizable to the general population. Moreover, as the study design is cross-sectional it does not confirm a cause-and-effect relationship. Finally this study did not look other factors related to RTI, such as driver behavior, car condition and the road and its related infrastructure.

\section{Conclusion}

In this study, the prevalence of RTI was found to be high. Socioeconomic status (wealthy and middle income), no education of guardian or family, mother's marital status (divorced), and leaving a child with another child for sometimes and most often were factors independently associated with RTI. The finding suggest that RTI prevention needs a critical consideration and the intervention strategies shall focus on low income, uneducated and families who practice leaving a child with another child and further study is recommended to explore the relationship between divorced marital status of the mother and RTI.

\section{Abbreviations}

AOR: Adjusted Odd Ratios; Cl: Confidence Interval; ED: Emergency Department; IRB: Institutional Review Board; OR: Odd Ratios; RTI: Road Traffic Incident

\section{Acknowledgements}

The authors would like to thank data collectors and the study participants for their dedicated cooperation and made the study possible.

\section{Funding}

University of Gondar is the source of the fund for this research. However, University has no role in the designing of the study, collection, analysis, and interpretation of data and in preparing the manuscript.

Availability of data and materials

All relevant data were within the manuscript.

\section{Authors' contributions}

BT carried out the study starting from conception, analysis and interpretation of data and drafting of the manuscript. BB participated in analysis and interpretation of data for important intellectual content and BA participated in critical review of the manuscript, data analysis and interpretation of the finding. All authors have read and approved the final version of the manuscript.

\section{Authors' information \\ 1. BTT is an assistant professor of critical care nursing at the School of Nursing, College of Medicine and Health Sciences, University of Gondar, Ethiopia. He has a Bachelor of Science Degree in Nursing, MSc in emergency medicine and critical care nursing specialization. \\ 2. BB is an assistant professor of mental health in the School of Nursing, College of Medicine and Health Sciences at University of Gondar, Ethiopia. He has a Bachelor of Science Degree in Nursing, MSc in mental specialization. \\ 3. BA is an assistant professor at the department of Biostatistics and Epidemiology, Institute of Public Health, College of Medicine and Health Sciences, University of Gondar, Ethiopia. He has a Bachelor of Science Degree in Nursing, MSc in Adult Health Nursing, and Masters of public health in biostatistics and epidemiology specialization.}

\section{Ethics approval and consent to participate}

Ethical clearance was obtained from the Institutional Review Board (IRB) of the University of Gondar, prior to the commencement of the data collection. Participants were informed about the purpose of the study and written informed consent was obtained from the parental and/or legal guardian. 


\section{Competing interests}

The authors declare that they have no competing interests.

\section{Publisher's Note}

Springer Nature remains neutral with regard to jurisdictional claims in published maps and institutional affiliations.

\section{Author details}

${ }^{1}$ College of Medicine and Health Science, School of Nursing, University of Gondar, P.O.Box: 196, Gondar, Ethiopia. ${ }^{2}$ Department of Epidemiology and Biostatistics, Institute of Public Health, College of Medicine and Health Sciences, University of Gondar, P.O.Box: 196, Gondar, Ethiopia.

Received: 13 February 2018 Accepted: 26 February 2019

Published online: 04 March 2019

\section{References}

1. Mthuli N, Charles L, Steve K, Victor M. Mortality in Africa: The Share of Road Traffic Fatalities African Development Bank; 2013.

2. WHO. Road traffic injuries. 2016.

3. Girma B, Getu S. Causes of road traffic accidents and possible counter measures on Addis ababa-Shashemene roads. Addis Ababa University Institutional Repositor. 2008.

4. Ludvigsson JF, Stiris T, Del Torso S, Mercier JC, Valiulis A, Hadjipanayis A European academy of Paediatrics statement: vision zero for child deaths in traffic accidents. Eur J Pediatr. 2017:176(2):291-2.

5. Kilbey P. Reported road actuality in Great Britain 2011 annual report Great Britain national statistics 2011

6. Brook A. Ethiopia among worst in traffic safety. Addis FORTUNE. 2015;780.

7. Total Ethiopia. Djibouti corridor road safety awareness campaign: Total Ethiopia in collaboration with the Federal Road Transport Authority (FRTA); 2015.

8. Fesseha HM, Sileshi T. Road traffic accident: the neglected health problem in Amhara National Regional State, Ethiopia. Ethiop J Health Dev. 2014;28(1).

9. Woldemichael K, Berhanu N. Magnitude and pattern of injury in Jimma university specialized hospital, south West Ethiopia. Ethiop J Health Sci. 2011;21(3):155-65.

10. Persson A. Road traffic accidents in Ethiopia: magnitude, causes and possible interventions. Advances in transportation studies. 2008;2008(15):5-16.

11. Ghaffar A, Hyder AA, Masud TI. The burden of road traffic injuries in developing countries: the 1st national injury survey of Pakistan. Public Health. 2004;118(3):211-7.

12. Jalalvandi F, Arasteh P, Safari Faramani R, Esmaeilivand M. Epidemiology of pediatric trauma and its patterns in Western Iran: a hospital based experience. Global J Health Sci. 2015;8(6):139-46.

13. Pretorius $\mathrm{CJ}$, Firthll GB. Road traffic accidents and orthopaedic injuries in children, vol. 9: SA orthop j Pretoria Jan; 2010. p. 3.

14. Kundal VK, Debnath PR, Sen A. Epidemiology of pediatric trauma and its pattern in urban India: a tertiary care hospital-based experience. J. Indian Assoc. Pediatr. Surg. 2017;22(1):33-7.

15. Mallikarjuna GP, Latha GS, Veeresh Babu DV, Thejraj HK. Prevalence of road traffic accident in children: retrospective study in tertiary Centre. Int J Contemp Pediatr. 2017;4(2).

16. Gupta RP, de Wit ML, McKeown D. The impact of poverty on the current and future health status of children. Paediatr Child Health. 2007;12(8):667-72.

Ready to submit your research? Choose BMC and benefit from:

- fast, convenient online submission

- thorough peer review by experienced researchers in your field

- rapid publication on acceptance

- support for research data, including large and complex data types

- gold Open Access which fosters wider collaboration and increased citations

- maximum visibility for your research: over $100 \mathrm{M}$ website views per year

At $\mathrm{BMC}$, research is always in progress.

Learn more biomedcentral.com/submissions 